\title{
Redactioneel
}

\section{Justice delayed is justice denied}

\author{
Prof. mr. J.H. (Jan) Crijns en mr. A. (Ton) de Lange*
}

Dit themanummer gaat over 'tijd' in het strafrecht. De focus ligt, zoals de titel van dit redactioneel al aangeeft, op tijdige rechtspraak. Hoewel het Nederlandse strafprocesrecht in het algemeen en de rechtspraak in het bijzonder sterk op efficiëntie is gericht (zeker in rechtsvergelijkend perspectief), betekent dit niet dat we genoegzaam achterover kunnen leunen. De ontwikkelingen in de maatschappij lijken steeds sneller te gaan, waarmee ook de verwachtingen van rechtzoekenden, overige betrokkenen en de maatschappij toenemen dat er door de rechter snel wordt beslist. Snelheid lijkt ook effectiever; justice delayed is justice denied. Snelheid heeft echter ook een schaduwzijde; zo mag snelheid niet ten koste gaan van de kwaliteit van de rechtspraak. Dit themanummer heeft in zekere zin dan ook het karakter van een discussiestuk. Een aantal auteurs nodigen de lezer hiertoe ook expliciet uit.

Zo wordt in de bijdrage van Vincent Mul de lezer nadrukkelijk uitgenodigd mee te denken. In zijn bijdrage ligt de focus op de logistiek van de strafrechtspraak. Hij schrijft in dit verband over 'doorligtijd' in plaats van de gebruikelijke term 'doorlooptijd'. 'Doorliggen' heeft in de medische wereld een negatieve connotatie; zo ook in het strafrecht. Strafzaken liggen naar zijn idee geregeld onnodig lang te wachten, zonder dat er iets mee gebeurt of iemand er actief mee bezig is. Als voorbeeld noemt hij een vonnis van de rechtbank waartegen hoger beroep wordt ingesteld, waarna het gemiddeld ruim vijf maanden duurt voordat de zaak uitgewerkt bij het hof ligt. In het geval er cassatie wordt ingesteld, duurt het vervolgens weer gemiddeld ruim vijf maanden voordat de zaak uitgewerkt bij de Hoge Raad ligt. Bij elkaar al snel een 'doorligtijd' van een jaar of meer. Dat moet veel

Jan Crijns is lid van de redactie van Boom Strafblad en hoogleraar strafen strafprocesrecht aan de Universiteit Leiden. Ton de Lange is lid van de redactie van Boom Strafblad en bestuurslid van het Hof Den Haag. korter kunnen, aldus Mul. Hij stelt dan ook verschillende oplossingen voor. Eén ervan is de herinvoering van de mogelijkheid een appeldagvaarding in persoon te betekenen, direct bij het instellen van het appel (BIPAD). Hiermee kan een snelle doorstroom naar de tweede lijn plaatsvinden. Een andere oplossing die hij noemt is de mogelijkheid van een strafrechtelijke rolzitting in hoger beroep, waarover ook eerder dit jaar in dit tijdschrift al is gepubliceerd. ${ }^{1}$ Ook meer regievoering buiten de zitting om is een optie waaraan Mul denkt.

Dit laatste is in lijn met de voorstellen van Hermine Wiersinga. In haar bijdrage ligt de focus vooral op de inhoudelijke afdoening van strafzaken in hoger beroep, waarbij ook zij de 'doorligtijd' wil aanpakken. In vervolg op eerdere voorstellen in de literatuur tot invoering van vonnis- en/of procesafspraken, is haar oplossing gelegen in het 'versneld procederen met behulp van procesafspraken'. Zij komt met een voorstel voor hoe de innovatiekamer van het Haagse hof oude zaken - op basis van consensus tussen de procesdeelnemers - versneld wil afdoen. Deze wijze van afdoening moet echter wel passen in het raamwerk van de rechtspraak van het EHRM met betrekking tot het recht op een eerlijk proces en de beginselen en uitgangspunten van ons huidige Wetboek van Strafvordering. Zij zoekt de ruimte om binnen die kaders tot een versnelde afdoening te komen in het voeren van regie voorafgaand aan de zitting. Ook zij sluit haar bijdrage af met een uitnodiging aan de lezer tot meedenken.

Joep Lindeman, Leonie van Lent en Benny van der Vorm bespreken het snelrecht, een ogenschijnlijk eenvoudige term. De term wordt vaak generiek gebruikt voor alles wat met snelle afdoening te maken heeft, ook de buitengerechtelijke. Het 'snelrecht' bestaat natuurlijk al langer (onder andere in de vorm van supersnelrecht), maar is

1. Zie A. de Lange, W.E.C.A. Valkenburg en J. van der Vegte, 'De rechtsstaat en het geld. Innovatie en financiering van de (appel)rechtspraak', Boom Strafblad 2021(1), p. 18-25. 
in de coronacrisis nadrukkelijker op de kaart gezet. Zo was er aan het begin van de crisis veel aandacht voor de 'coronaspugers' en later de 'avondklokrellers'. De auteurs waarschuwen echter voor oneigenlijk gebruik. Het (super)snelrecht heeft thans een duidelijke koppeling met het voorarrest en de auteurs menen dat het snelrecht nu vooral gebruikt wordt voor het direct opsluiten van verdachten, waarmee mogelijke maatschappelijke onrust kan worden gedempt. Zij pleiten voor een beleid waarmee een aantal procedurele aspecten (zoals termijnen, verdedigingsrechten en de positie van slachtoffers) nader wordt gereguleerd, zodat alle betrokken partijen begrijpen wat hun te wachten te staat als ze met een snelrechtprocedure te maken krijgen. Ook een systeem waarin snelle berechting vooropstaat, moet immers zijn voorzien van faciliterende randvoorwaarden en procedurele waarborgen met betrekking tot de rechtsbescherming.

In zijn column geeft Patrick van der Meij een geheel andere inkleuring aan het begrip 'tijd'. Hij stelt zelfs dat strafrechtspraak en 'tijd' niet samengaan. Volgens hem heeft de coronacrisis juist het onderliggend lijden van de Nederlandse rechtspraak blootgelegd: er is ook onder normale omstandigheden nooit genoeg tijd om een strafzaak goed te behandelen. Veel in deze verstoorde verhouding van rechtspraak tot 'tijd' is terug te voeren tot een gebrek aan capaciteit en een matige financiering, wat betekent dat de ziekte van het efficiëntiedenken diep is doorgedrongen in de rechtspraak. Dit is zonder meer problematisch: door haar moeizame verhouding tot 'tijd' dreigt de rechtspraak haar gezag te verspelen.

Leo van Dorst ten slotte heeft het over tijd in de zin van 'over tijd'; verjaring dus. In dat verband brengt hij onder meer de 'wet van het vergeten' ter sprake. Naast slachtoffers van een delict of nabestaanden die - ook na verloop van zeer lange tijd - nog behoefte hebben aan de bestraffing van de verdachte ('wij hebben levenslang'), zijn er ook veel slachtoffers en nabestaanden die het vreselijke dat hun is overkomen, in de loop van de tijd hebben weten te verwerken en een plaats in hun leven hebben gegeven. Een wetgever die zich ter onderbouwing van voorstellen tot verlenging of zelfs afschaffing van verjaringstermijnen beroept op wat 'de' slachtoffers en nabestaanden vinden, begeeft zich volgens Van Dorst daarom op glad ijs. Als altijd in het recht gaat het uiteindelijk om een afweging van belangen. En aangezien het afwegen van belangen bij uitstek de taak van de rechter is, is afschaffing van de bestaande regeling van automatische verjaring zeker pleitbaar. De auteur komt vervolgens bij wijze van tussenweg met de suggestie voor een regeling die ertoe strekt dat na het verstrijken van de verjaringstermijn in beginsel geen vervolging meer kan worden ingesteld, behoudens in gevallen waarin de rechter verlof tot het instellen van vervolging verleent op de grond dat het algemeen belang dat dringend eist. In die opzet wordt de zaak al in een vroeg stadium - het gaat dus ook in dit geval weer over 'tijd' - aan de rechter voorgelegd om hem de rechtens relevante belangen te laten afwegen.
Zoals Lindeman c.s. laten zien kan rechtspraak ook te snel, maar over het geheel genomen zouden vele belangen - waaronder niet in de laatste plaats die van de verdachte - gediend zijn met tijdiger rechtspraak. Wij hopen dan ook dat dit nummer over 'tijd' in het strafrecht $\mathrm{u}$ tot nadenken aanzet en dat u gebruikmaakt van de uitnodiging van onze auteurs om met hen de discussie aan te gaan over de verschillende voorstellen om de verhouding tussen 'tijd' en strafrecht minder moeizaam te maken. Enig tijdsverloop tussen het feit en de berechting kan zonder meer bijdragen aan de afstand die voor een kwalitatief goede berechting noodzakelijk is; dit tijdsverloop mag echter nooit zodanig groot worden dat dit afdoet aan het nut van de berechting zelf. Aan het slot van dit redactioneel gekomen, rest ons te memoreren dat begin dit jaar ons zeer gewaardeerde mederedactielid Jan Leliveld heeft besloten dat zijn tijd als lid van de redactie van dit tijdschrift erop zit. Mede namens de andere redactieleden willen wij Jan zeer hartelijk danken voor zijn jarenlange toewijding, inspiratie en bevlogenheid, ook in de tijd dat wij de overstap maakten naar een nieuwe uitgever. Zonder Jan had Boom Strafblad niet gestaan waar het nu staat. Gelukkig hebben wij inmiddels in de persoon van Eva Huls - in het dagelijks leven onder meer werkzaam als advocaat in dienstbetrekking bij Defence for Children - een waardig opvolger van Jan gevonden. Dat neemt niet weg dat we de immer vrolijke inbreng van Jan gedurende onze redactievergaderingen zeer missen. Jan, nogmaals buitengewoon veel dank voor alles! 